Anders staat het echter met de invloed van de inkomstenbelasting. Het is de N.V. Finaco bij haar werkzaamheden gebleken, dat deze laatste heffing van wezenlijke beteekenis kan zijn bij de keuze van de obligatieleening waarin wordt belegd.

Het is namelijk een weinig bekend, maar daarom niet minder belangrijk feit, dat de bedragen welke de beleggers jaarlijks aan inkomstenbelasting moeten betalen, mede bepaald worden door de aflossingsvoorwaarden van de obligatieleeningen waarin hun bezit is geinvesteerd. Dit wordt veroorzaakt doordat onder het tegenwoordige Nederlandsche belastingstelsel wel de renteontvangst op obligaties als ,inkomen" wordt beschouwd en dus voor belastingheffing in aanmerking komt, maar dat zulks met de kapitaalwinst niet het geval is. Een perpetueele leening werpt uitsluitend rente af, welke dus geheel belast wordt. De inkomsten uit een lossende leening bestaan uit jaarlijksche renteontvangsten en kapitaalwinst bij uitloting. Hiervan worden alleen de renteontvangsten getroffen door den fiscus. Dat het bovenstaande van beteekenis kan zijn, moge blijken uit het volgende voorbeeld:

Een rentenier bezit $f 30.000$. - en heeft geen verdere bron van inkomsten. Hij wenscht zijn vermogen geheel te investeeren in Staatsleeningen. Daarbij heeft hij de keuze tusschen een $3 \%$ rentend perpetueel fonds en een eveneens $3 \%$ rentende leening, welke in 20 gelijke jaarlijksche termijnen wordt gedelgd. Het eerste fonds noteert 60 en laat dus een rendement van $\frac{3}{60}=5 \%$, de lossende leening is tegen een koers van $851 / 4$ te krijgen en laat op dit niveau een rendement tot den vervaldag van eveneens $5 \%$. Oogenschijnlijk is het rendement op beide leeningen dus even hoog.

Wanneer de rentenier zijn $f 30.000$ in de $3 \%$ perpetueele leening belegt ontvangt hij, aangezien de aankoopkoers $60 \%$ bedraagt, een nominaal bedrag groot $f 50.000$. - . Het jaarlijksche rente-inkomen op deze investitie bedraagt dus $f 1.500$. Dit is in zijn geheel belastbaar inkomen, zoodat de rentenier over $f 1.500$. - belasting moet betalen. Deze bedraagt bij de voor het belastingjaar 1940/41 geldende tarieven voor een Amsterdammer:

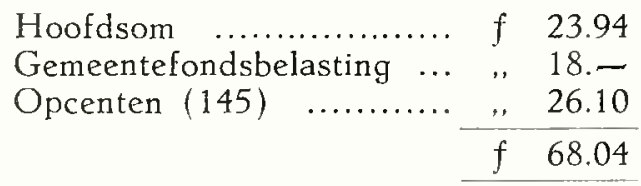

Belegt de rentenier zijn gelden in de lossende leening, dan verwerft hij $f 35.200$ nominal, aangezien het voor investitie beschikbare bedrag $f 30.000$ was en de ankoopkoers $851 / 4 \%$. De renteontvangst op deze investitie bedraagt $f$ 1.056.-. Voorts maakt de rentenier bij uitloting van zijn stukken een kapitaalwinst. De jaarlijksche gemiddelde contante waarde van deze kapitaalwinst bedraagt circa $f$ 444. - hetgeen zijn gemiddeld jaarlijksche inkomen op $\pm f$ 1.500. - brengt. Dit komt dus overeen met het inkomen, dat hij op de investitie in het perpetueele fonds ontvangt. Belasting wordt echter alleen geheven van de $f$ 1.056. - renteinkomen. Deze bedraagt:

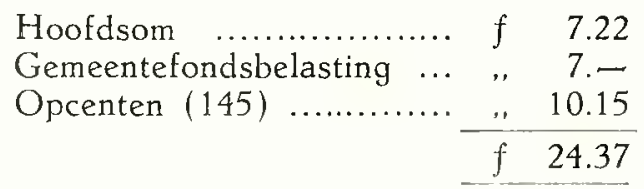

of belangrijk minder $(64 \%)$ dan de belasting welke moest worden betaald, indien het vermogen in perpetueele fondsen was geinvesteerd.

Vanzelfsprekend is bij grootere vermogens, waarvan hoogere belastingen worden geheven het verschil quantitatief belangrijker. Op een bezit van $f \quad 600.000$ bijvoorbeeld bedraagt bij investitic in perpetueele leeningen, op de hierboven aangegeven voorwaarden, het jaarlijksch rente-inkomen $f 30.000$. De belasting op dit inkomen is voor het belastingjaar 1940/' 41 $f$ 6.427.79. Bij investitie in een $3 \%$ rentende leening, die in 20 gelijke jaariijksche termijnen gedelgd wordt bedraagt het rente-inkomen $f 21.114$ en de jaarlijksche gemiddelde contante waarde van de kapitaalwinst † 8.886. - samen dus $f$ 30.000. - Belasting wordt alleen geheven van het renteinkomen. Jeze bedraagt $f 4.062 .71$ of $f 2.365$. - minder dan de belasting weike bij belegging in perpeturele leeningen betaald moest worden. Dit zijn vrij aanzienlijke bedragen, zoodat de particuliere belegger goed zal doen met het bovenstaande bij zijn investities rekening te houden.

Het valt gemakkelijk in te zien, dat leeningen die snel gedelgd worden, en waarbij dus de niet belaste kapitaalwinst een groote plaats inneemt, uit een belastingoogpunt voor den belegger het aantrekkelijkst zijn. De beteekenis van een dergelijke snelle delging wordt bovendien grooter naarmate de betrokken leening verder onder pari noteert. Het voordeel van deze snellere delging is echter slechts exact te berekenen, in dien de totale inkomsten van den betrokken belegger bekend zijn, en men dus vast kan stellen hoeveel inkomstenbelasting bij belegging in perpetueele of lang loopende leeningen betaald moet worden en hoeveel belasting men verschuldigd is bij de investitie in kortloopende fondsen. Deze gegevens dient men van geval tot geval te verzamelen. Het is dus niet mogelijk een berekening te maken, welke voor alle beleggers gezamenlijk geldt.

Uit het bovenstaande volgt ook, dat het voor de ontvangers der inkomstenbelasting, de Staat en de Gemeenten, voordeeliger is leening a pari of boven pari uit te brengen, dan fondsen beneden pari te emitteeren. Dat het daarbij om niet te verwaarloozen bedragen gaat, moge een enkel voorbeeld illustreeren.

Op 10 November 1936 werd een $3 \%$ rentende leening. groot $f 100.000 .000$ geëmitteerd tegen een koers van $953 / 4 \%$. Daar deze leening in 20 jaar door middel van jaarlijksche gelijke termijnen wordt afgelost, bedroeg het rendement tot den vervaldag op de koers van uitgifte $3.48 \%$. Hetzelfde rendement wordt genoten bij uitgifte à pari van een $3 \frac{1}{2} \%$ rentende leening, welke in 20 gelijke jaarlijksche termijnen wordt gedelgd. Oogenschijnlijk maakt het dus niets uit of een $3 \%$ leening a $953 / 4 \%$, dan wel een $31 / 2 \%$ rentende leening à pari wordt geëmitteerd. In het eerste geval keert de staat echter het eerste jaar $f 3.000 .000$ rente uit waarover belasting betaald moet worden, in het laatste geval $f 3.500 .000$. Het tweede jaar zijn deze bedragen respectievelijk f 2.850 .000 en $f 3.325 .000$ enz. Een eenvoudige berekening toont aan, dat de lagere belastingopbrengst, welke van deze eerste wijze van emitteeren het gevolg is, gemiddeld van de orde van $f 25.000$ a $f 30.000$ per jaar is, dat is dus $f 500.000$ a $f 600.000$ voor de geheele leeningsduur, indien alle obligaties door particuliere beleggers worden gekocht.

J. VOET

\section{NIEUWS IN ZAKE WETGEVING, RESOLUTIES EN BESLISSINGEN OP HET GEBIED DER BELASTINGEN}

Red.: Mr Dr E. TEKENBROEK

(Bijdragen en mededeelingen zende men aan den Secretaris der Redactie)

\section{Inbreng van activa in een N.V, tegen te lage waarde}

Het komt wel voor, dat bij de oprichting van cen N.V. activa worden ingebracht tegen een te lage warde. Bijv. als 
men een bedrijf inbrengt zonder rekening te houden met de goodwill, die er in steekt. De vraag rijst dan of bij de vaststelling op een later tijdstip van winst in de zin der D.T.B., die in de N.V. aanwezig geacht kan worden, rekening gehouden moet worden met deze meerdere waarde van de ingebrachte activa op het moment van inbreng, dan wel of de lage waarde waarvoor die activa zijn ingebracht als uitgangspunt moet worden genomen.

In een zeer belangrijk arrest dd. 25 October ' 39 heeft de H.R. deze vraag in laatstbedoelde zin beantwoord. De H.R. overwoog daarbij o.m.

,dat nu derhalve bedoelde onroerende goederen op den ,.grondslag van genoemde waarde als storting op de daartegen ,uitgegeven aandeelen zijn aanvaard, de Raad van Beroep "terecht reeds uit dien hoofde heeft beslist, dat de eventueele "meerdere waarde ten tijde van den inbreng niet tot het kapi"taal van belanghebbende kan worden gerekend;"

., dat toch voor de heffing van de D.T.B. agio niet als kapi,taal kan worden aangemerkt, indien het niet als zoodanig is ,overeengekomen en in de boeken van de betrokken N.V. is "opgenomen en in stand gehouden."

Zie over dit arrest Van Soest in W.B. 3528 en Adriani in W.F.N.R. 3662.

Volledigheidshalve zij vermeld, dat voor de heffing van registratierecht een ander standpunt wordt ingenomen. Voorts zij gewezen op het arrest van de H.R. dd. 26 Juni '35 B 5886 , waaruit op te maken valt, dat de H.R. voor het ..spiegelbeeld": inbreng voor te hooge waarde, een soortgelijke beslissing nam. Bijster bevredigend achten wij deze rechtspraak intusschen niet, maar ze heeft het praktische voordeel dat ze disputen over de waarde van ingebrachte zaken van jaren her afsnijdt.

\section{Waardeering incourante aandeelen}

Bij de waardeering van de geldswaarde van de incourante aandeelen voor de V.B. van den directeur-eenig-aandeelhouder hield de Amsterdamsche Raad van Beroep blijkens zijn uit spraak dd. 27 Januari '38 (B 6955), naast de intrinsieke waarde ook rekening met de te verwachten verliezen in het bedrijf der N.V. en met het feit, dat over de in de N.V. aanwezige reserves door den directeur-aandeelhouder niet kan worden beschikt zonder dat dividendbelasting betaald moet worden.

Blijkens een bij de gepubliceerde uitspraak gevoegde noot heeft de Minister zich hiermede kunnen vereenigen.

\section{Berekening van Duitsche inkomsten}

Velen hier te lande trekken inkomsten uit Duitschland en hebben als zoodanig te maken met de zich gedurig wijzigende en voor de toekomst onzekere transferbepalingen.

In dit verband is het van belang dat de H.R. met zijn arrest dd. 24 Mei '39 (B 6918) in principe heeft uitgemaakt, dat de waarde in Nederlandsch geld van die Duitsche inkomsten moet worden vastgesteld op het tijdstip, waarop het inkomen verkregen werd en dus niet kan worden gesteld op het bedrag dat, wellicht maanden nadien, effectief in Nederlandsche valuta geincasseerd werd.

\section{Ontbreken van ambtelijk verzuim bij navordering}

lemand woonde 1 Mei 1936 hier te lande en had een inkomen, dat hem voor een aanslag in de I.B. in aanmerking bracht. De Inspecteur kreeg daarvan eerst kennis door de aangifte van den belastingplichtige voor 1937/38. Binnen een maand na die aangifte, het was inmiddels 1937 geworden, legde de Inspecteur voor $1936 / 37$ alsnog een primitieve aanslag op, gedateerd 31 Jan. ' 38 .
De belastingplichtige meende, dat hier geen primitieve aanslag maar een navorderingsaanslag opgelegd had dienen te worden, omdat ten onrechte een aanslag over 1936/37 achterwege was gebleven. De Inspecteur meende, dat waar hem in deze geen verwijt trof (hij wist niet en kon niet weten, dat voor $1936 / 37$ een aanslag opgelegd diende te worden). De Raad van Beroep in 's-Hertogenbosch stelde de inspecteur in het gelijk, maar de H.R, dacht daar anders over. Met zijn arrest dd. 21 Juni ' 39 werd de opgelegde primitieve aanslag vernietigd. Overwogen werd daarbij, dat hier het geval aanwezig was, dat een aanslag ten onrechte was achterwege gebleven, dus art. 82 I.B. toepassing moest vinden. Het feit, dat de Inspecteur geen verwijt trof, achtte de H.R. in deze geheel irrelevant. Als argument werd door de H.R. o.m. aangevoerd, dat uit de M. v. T. blijkt, dat navordering niet is, toegelaten tot herstel van ambtelijk verzuim. Ergo voor een niet ambtelijk verzuim is art. 82 juist in de wet opgenomen.

\section{Is boete c.a. opgelegd wegens overtreding van de landbouwcrisiswetten een bedrijfslast?}

Een belastingplichtige had de landbouwcrisiswet overtreden, deswege een boete van $f$ 600.- gekregen. Hij wilde deze $f$ 600. - mitsgaders de kosten van rechtskundige bijstand ad $f$ 212.29, in totaal dus $f 812.29$ als bedrijfskosten t.l.v. zijn verlies- en winstrekening brengen. Hij betoogde o.m. dat die overtredingen door zijn personeel buiten zijn voorkennis zijn begaan. De Inspecteur weigerde deze aftrek, zoo ook de Raad van Beroep te 's-Hertogenbosch.

De H.R. handhaafde de uitspraak (arrest dd. 28 Juni 1939) daarbij overwegende:

„,dat het toch betreft gelden, verschuldigd geworden inge..volge overtreding van publiekrechtelijke voorschriften, gel.dende voor de uitoefening van een bedrijf, als door belang, hebbende uitgeoefend;

,,dat belanghebbende gehouden was er zorg voor te dra.,gen, dat in zijn bedrijf niet in strijd met die voorschriften ,werd gehandeld en, daarin te kort schietende en, deswege ,,vervolgd, boete en bijkomende kosten beloopende, noch in.gevolge art. 7. noch krachtens art. 10 I.B. de ter zake dier , overtreding betaalde gelden in mindering kon doen komen ,van zijn bedrijtswinst;

,dat dit niet anders wordt, indien van de belaste bedrijfs,winst baten mochten deel uitmaken, die te danken zijn aan "die ongeoorloofde wijze van bedrijfsuitoefening";

Het wil ons voorkomen, dat hier een uitermate stringent standpunt wordt ingenomen. Mogelijk dat hierbij van invloed is geweest het feit, dat de Raad van Beroep o.m. vaststelde, dat de contrōle op het personeel niet bijster streng geweest is. De H.R. overwoog dan ook, dat belastingplichtige in dit opzicht te kort is geschoten.

TEKENBROEK

\section{BOEKBESPREKING}

Vijf en twintig jaren Gemeentelijke financieele administratie en haat controle. Gedenkschrift ter gelegenheid van de 25-jarige werkzaamheid van het Centraal Bureau voor Verificatie en Financieele adviezen van de Vereeniging van Nederlandsche Gemeenten.

Het is niet zoozeer om der wille van het op zich zelf gedenkwaardige feit van het 25-jarig bestaan van het Verificatiebureau van de Vereeniging van Nederlandsche Gemeen- 